\title{
A combination of levosimendan and N-Acetylcysteine shows significant favorable efficacy on experimental liver ischemia/reperfusion injury
}

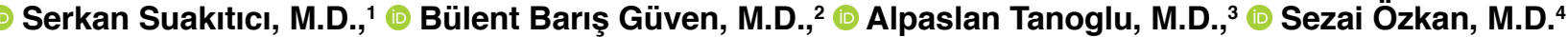

\author{
'Department of Anesthesiology, Marmaris State Hospital, Muğla-Turkey \\ 2Department of Anesthesiology, Health Science University, Sultan 2. Abdülhamid Han Training and Research Hospital, İstanbul-Turkey \\ ${ }^{3}$ Department of Gastroenterology, Health Science University, Sultan 2. Abdülhamid Han Training and Research Hospital, İstanbul-Turkey \\ ${ }^{4}$ Department of Anesthesiology, Medipol University Çamlıca Hospital, İstanbul-Turkey
}

\begin{abstract}
BACKGROUND: Ischemia-reperfusion injury (IRI) is cellular damage that emerges from re-oxygenation of a hypoxic organ. In the present study, we aimed to examine the effects of a combination of levosimendan, an inotropic agent, and N-Acetylcysteine, the precursor of antioxidants and glutathione, in an experimental liver IRI model.
\end{abstract}

METHODS: In this study, 38 rats were randomly divided into five groups. Before the ischemia, study arms were given physiological saline solution, N-Acetylcysteine (NAS), levosimendan or a combination of NAS+levosimendan in a predetermined amount and duration, and the infusion was continued until the end of this study. The hepatic pedicle was occluded using an atraumatic vein clamp, and 60 minutes of ischemia was achieved. The clamp was then opened and 60 minutes of reperfusion was ensured. Liver tissue samples were obtained after sacrifice, and tissue malondialdehyde (MDA) and myeloperoxidase (MPO) levels were determined. Serum Tumor Necrosis Factor (TNF)- $\alpha$, aspartate aminotransferase (AST), alanine aminotransferase (ALT) and MPO levels of blood samples were also measured.

RESULTS: Among the histopathological changes in the liver tissue after IRI, differences between groups were statistically significant in the injury scoring system based on congestion, vacuolization and necrosis levels. Histopathological injury score, plasma MPO, AST, ALT, tissue MPO and tissue MDA values were statistically significantly lower in the treatment groups, prominently in the levosimendan and NAS combination group concerning liver histopathological damage.

CONCLUSION: The use of a levosimendan plus NAS combination in liver IRI markedly suppressed inflammation and oxidative stress and significantly reduced liver ischemia-reperfusion injury and can be recommended for decreasing IRI instead of single agent use of levosimendan or NAS.

Keywords: Ischemia-reperfusion injury; levosimendan; liver; N-Acetylcysteine.

\section{INTRODUCTION}

Ischemia is the condition of a tissue or an organ's deprivation of oxygen $\left(\mathrm{O}_{2}\right)$ due to insufficient perfusion from a decrease or a cessation of arterial or venous blood flow. Ischemia causes cell death by leading to reversible or irreversible cellular damage because of decreased cellular energy stocks and accumulation of toxic metabolites. ${ }^{\left[{ }^{I]}\right.}$ Ischemia reperfusion inju- ry (IRI) is the cellular damage emerging from the re-oxygenation of a hypoxic organ. Toledo-Pereyra et al. ${ }^{[1]}$ described IRI in the liver for the first time in 1975 in experimental liver transplantation. In addition to transplantation surgery, liver ischemia may occur in patients undergoing surgery for trauma, cancer or biliary obstruction and stenosis. It may also develop after a hemodynamic or cardiogenic shock period without any surgical intervention. ${ }^{[1,2]}$

Cite this article as: Suakıtıcı S, Güven BB, Tanoglu A, Özkan S. A combination of levosimendan and N-Acetylcysteine shows significant favorable efficacy on experimental liver ischemia/reperfusion injury. Ulus Travma Acil Cerrahi Derg 2021;27:381-388.

Address for correspondence: Bülent Barış Güven, M.D.

SBÜ, Sultan 2. Abdulhamid Han Eğitim ve Araştırma Hastanesi, Anesteziyoloji Servisi, Üsküdar, İstanbul, Turkey

Tel: +90 216 - 5422020 E-mail: barguv@gmail.com 
Many hepatocyte-preserving agents, which are believed to block the pathophysiologic mechanisms thought to be responsible for IRI, such as allopurinol, $\alpha$-tocopherol, mannitol, dopamine, prostaglandin, active carbon hemoperfusion, glucagon, carnitine, chlorpromazine, aprotinin, methylprednisolone, deferoxamine, cyclosporine, aspartic acid, ubiquinone, thrombocyte-activating factor antagonists, verapamil and superoxide dismutase. and their healing effects on IRI were examined using experimental IRI models. ${ }^{[2]}$

$\mathrm{N}$-acetylcysteine (NAS) has antioxidant properties. Cysteine is an antioxidant with a thiol group that contains sulfur and reduces organic molecules by donating an electron. NAS is a glutathione precursor and used in the prevention and treatment of oxidative stress-caused diseases, sepsis and as a mucolytic agent in various respiratory tract diseases. ${ }^{[2]}$ Levosimendan is a drug used in treating acute and decompensated heart failure. It creates a positive inotropic effect by increasing the sensitivity of contractile proteins to calcium $\left(\mathrm{Ca}^{++}\right)$, as well as having vasodilatation and anti-ischemic effects by opening potassium $\left(\mathrm{K}^{+}\right)$-sensitive ATP channels. ${ }^{[3]}$

In this study, we aimed to examine the combined and separate effects of NAS and levosimendan on liver IRI by establishing an experimental IRI model.

\section{MATERIALS AND METHODS}

In this experimental study, we used healthy male Wistar-albino rats aged between 16-20 weeks and weighing 250-300 g. We kept the rats in an experimental animal laboratory at $20-22^{\circ} \mathrm{C}$ ambient temperature in a circadian rhythm (I2 hours of day and 12 hours of night). The Local Ethics Committee of Animal Experiments, Marmara University (protocol no. 87.2012), approved this study protocol and experimental method. Following approval of the ethics committee, 38 rats were randomly divided into five groups (six in the sham group and eight rats in each of the other groups).

All the rats were fasted for eight hours before the operation. All rats were weighed before the procedure and the body weights were recorded. We gave the rats a combination of $100 \mathrm{mg} / \mathrm{kg}$ intraperitoneal ketamine and $5 \mathrm{mg} / \mathrm{kg}$ chlorpromazine for general anesthesia. We repeated I/3 of the initial dose on an hourly basis.

We performed a cut-down for vascular access and put a 26 -gauge angiocath in the right jugular vein. We gave $150 \mathrm{IU} /$ $\mathrm{kg}$ heparin intravenously to prevent clotting. We shaved the frontal abdominal wall. We cleaned the skin using 10\% povidone-iodine solution. We approached the liver through a midline incision. The surgical operation in Group I consisted only of laparotomy. Groups II, III, IV and V, after laparotomy, we pulled the cecum towards the subject's left foreleg and took the bowels out of the abdomen. We found the portal vein under the liver at the root of the small intestinal mesentery.
After infusing the pre-calculated doses and equal volumes of physiological saline solution to (Group II), NAS to (Group III), levosimendan to (Group IV), and NAS + levosimendan combination to (Group V) with ten minutes intervals, the portal vein, and hepatic artery were clamped using an atraumatic microvascular clamp. We continued to infuse the physiological saline solution, NAS, levosimendan, and NAS+levosimendan combination during the ischemia and IR period. A total of I 20 minutes of study procedure, 60 minutes of ischemia and 60 minutes of reperfusion was the same for all groups. All the animals in this study received equal amounts of fluid intravenously. At the end of the procedure, we removed the liver and took tissue samples. We also took blood samples from the left atrium. We then sacrificed the rats with IV thiopental overdose.

\section{Study Groups}

Group I (Sham Group, pseudo-operated, n=6): The animals in this group underwent only laparotomy under general anesthesia, with duration equal to the duration of IR (I 20 minutes). No IR was applied during this time.

Group II (Ischemia/Reperfusion + Saline Group, Control Group, IR+S, $\mathbf{n = 8 ) : ~ T h e ~ a n i m a l s ~ i n ~ t h i s ~ g r o u p ~ u n d e r - ~}$ went laparotomy under general anesthesia, followed by 60 minutes of reperfusion after 60 minutes of ischemia. Intravenous saline solution implementation was started 10 minutes before the ischemia, and the infusion was continued during the IR period.

\section{Group III (Ischemia/Reperfusion + N-Acetylcysteine} Group, IR+NAS, $\mathbf{n = 8 ) : ~ T h e ~ a n i m a l s ~ i n ~ t h i s ~ g r o u p ~ u n d e r - ~}$ went laparotomy under general anesthesia, followed by 60 minutes of reperfusion after 60 minutes of ischemia. Ten minutes before the ischemia started, $150 \mathrm{mg} / \mathrm{kg}$ NAS loading dose was intravenously infused for 10 minutes. During the IR, NAS infusion was continued at a dose of $20 \mathrm{mg} / \mathrm{kg} / \mathrm{hour}$.

Group IV (Ischemia/Reperfusion + Levosimendan Group, IR+L, $\mathbf{n = 8 ) : ~ T h e ~ a n i m a l s ~ i n ~ t h i s ~ g r o u p ~ u n d e r w e n t ~}$ laparotomy under general anesthesia, followed by 60 minutes of reperfusion after 60 minutes of ischemia. Ten minutes before the ischemia started, $12 \mathrm{mcg} / \mathrm{kg}$ levosimendan loading dose was intravenously infused for 10 minutes. During the $\mathrm{IR}$, levosimendan was continued at a dose of $0.2 \mathrm{mcg} / \mathrm{kg} / \mathrm{min}$.

\section{Group V (Ischemia/Reperfusion + N-Acetylcysteine +} Levosimendan Group, IR+NAS+L, $\mathbf{n = 8}$ ): The animals in this group underwent laparotomy under general anesthesia followed by 60 minutes of reperfusion after 60 minutes of ischemia. 10 minutes before the ischemia started, $12 \mathrm{mcg} /$ $\mathrm{kg}$ levosimendan + $150 \mathrm{mg} / \mathrm{kg}$ NAS loading dose was intravenously infused for 10 minutes. During the IR, NAS infusion was continued at a dose of $20 \mathrm{mg} / \mathrm{kg} /$ hour. During the IR, 0.2 $\mathrm{mcg} / \mathrm{kg} / \mathrm{min}$ levosimendan and $20 \mathrm{mg} / \mathrm{kg} /$ hour NAS infusions were continued. 
Table I. Liver damage scores of groups

\begin{tabular}{|c|c|c|c|c|c|}
\hline & Group I & Group 2 & Group 3 & Group 4 & Group 5 \\
\hline & Mean $\pm S D$ & Mean $\pm S D$ & Mean $\pm S D$ & Mean士SD & Mean \pm SD \\
\hline Congestion & $0.33 \pm 0.52$ & $3 \pm 0.93$ & $2 \pm 0.76$ & $0.75 \pm 0.71$ & $0.63 \pm 0.74$ \\
\hline Vacuolization & $0 \pm 0$ & $2.88 \pm 1.25$ & $0.88 \pm 0.64$ & $0.5 \pm 1.07$ & $0.38 \pm 0.74$ \\
\hline Necrosis & $0 \pm 0$ & $1.5 \pm 1.2$ & $0.5 \pm 0.76$ & $0.25 \pm 0.46$ & $0.13 \pm 0.35$ \\
\hline
\end{tabular}

SD: Standard deviation.

Table 2. Statistical analysis of liver damage scores of groups

\begin{tabular}{|c|c|c|c|c|c|c|c|c|c|c|c|}
\hline Differences between groups & & $1-2$ & $1-3$ & $I-4$ & $1-5$ & $2-3$ & $2-4$ & $2-5$ & $3-4$ & $3-5$ & 4-5 \\
\hline Congestion & $P^{*}$ & $<0.001^{* *}$ & $<0.00 I^{* *}$ & 0.25 & 0.46 & $0.046^{* *}$ & $<0.001^{* *}$ & $<0.001^{* *}$ & $0.01^{* *}$ & $0.01^{* *}$ & 0.69 \\
\hline Vacuolization & $\mathrm{P}^{*}$ & $<0.001^{* *}$ & $0.01^{* *}$ & 0.20 & 0.20 & $0.01^{* *}$ & $<0.001^{* *}$ & $<0.001^{* *}$ & 0.12 & 0.11 & 0.94 \\
\hline Necrosis & $\mathrm{p}^{*}$ & $0.01^{* *}$ & 0.11 & 0.20 & 0.39 & 0.08 & $0.02^{* *}$ & $0.01^{* *}$ & 0.52 & 0.24 & 0.54 \\
\hline
\end{tabular}

We placed parts of liver tissue samples in 10\% formaldehyde solution for histopathological examination. We also placed small portions of liver tissue samples in Eppendorf tubes to measure the myeloperoxidase (MPO) and malondialdehyde (MDA) levels, the indicators of inflammation and oxidative stress, respectively. Blood samples were centrifuged, and serum samples were kept at $-80 \mathrm{C}^{\circ}$ to measure the degree of inflammation by measuring tumor necrosis factor- $\alpha$ (TNF- $\alpha$ ) and MPO, as well as the degree of liver tissue damage by measuring AST and ALT.

\section{RESULTS}

\section{Histopathological Results}

The findings obtained in this study showed that IRI caused various histopathological changes in the livers of the rats in experimental groups. According to the damage scoring sys- tem based on congestion, vacuolization and necrosis levels of liver tissue (Table I), statistically significant differences were found between the groups $(p<0.001)$ (Table 2$)$.

The average sinusoidal congestion score was minimal in Group I $(0.33 \pm 0.52)$ and maximum in Group II $(3 \pm 0.93)$. The difference between the groups was statistically significant $(p<0.001)$. The mean cytoplasmic vacuolization score was minimum in Group I $(0 \pm 0)$ and maximum in Group II $(2.88 \pm 1.25)$. The difference between the groups was statistically significant $(p<0.00 \mathrm{I})$. The mean cellular necrosis score was minimum in Group I $(0 \pm 0)$ and maximum in Group II (I.5 \pm 1.2$)$. Since the differences between the groups regarding mean scores of congestion, vacuolization and necrosis were statistically significant, we statistically compared the groups in pairwise form. In examining the liver damage scores of the groups, we found statistically significant differences in conges-
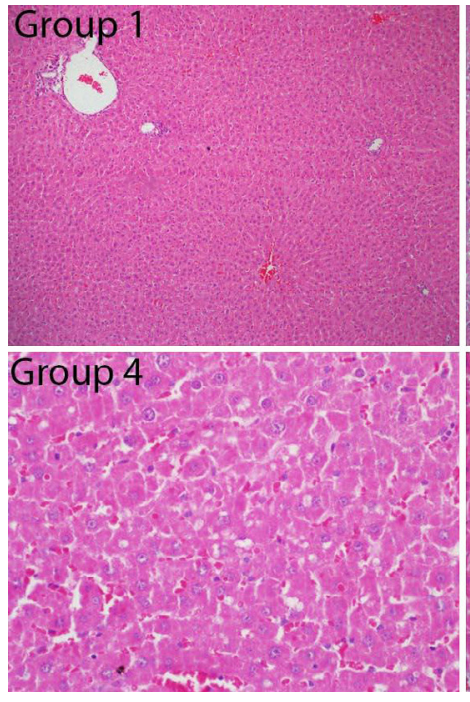
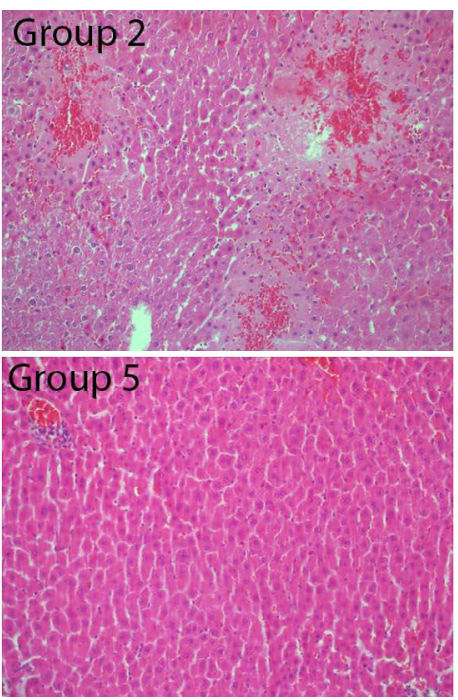

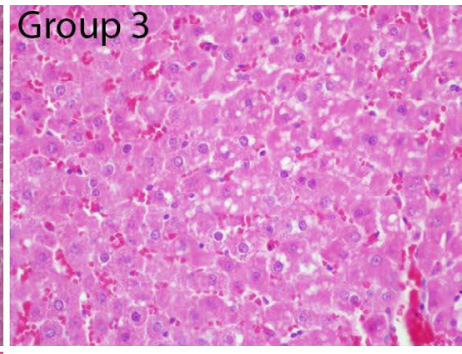

Figure 1. Hematoxylin and eosin (H\&E) staining of liver tissues. Group 1. Normal liver tissue appearance (H\&E, X100) Group 2. Ischemia-reperfusion group, severe cytoplasmic congestion, vacuolization and necrosis are existing (H\&E, X400) Group 3. N-Acetylcysteine. 
tion and vacuolization scores, and the groups were compared in a pairwise manner (Table 2). The average congestion and vacuolization scores of Group II were significantly higher than the other groups $(p<0.05)$ (Fig. I).

\section{Biochemical Results}

The minimum AST score was in Group I as 37.05 \pm 23.99 , whereas the maximum value was in Group II as I0I.13 14.91 . The difference between the groups was statistically significant $(p<0.0 I)$. The minimum ALT score was in Group I as $31.48 \pm 5.12$, whereas the maximum score was in Group II, $77.61 \pm 22.18$ (Table 3). The difference between the groups was statistically significant $(p<0.0 \mathrm{I})$. Since the differences between groups regarding AST and ALT scores were statistically significant, the groups were statistically compared pairwise. The mean AST and ALT scores of Group II were statistically significantly higher than the other groups $(p<0.05)$ (Table 4).

The minimum TNF- $\alpha$ score was in Group I as $176.67 \pm 56.15$, whereas the maximum score was $245.88 \pm 62.12$ in Group
II. The difference between the groups was not statistically significant $(p=0.23)$. The minimum serum MPO score was $7.64 \pm 0.63$ in Group I, whereas the maximum score was in Group II as $24.25 \pm 6.05$. The difference between the groups was statistically significant $(p<0.0 \mathrm{I})$ (Table 5$)$.

For the MPO (serum) level, the mean level of Group I was statistically lower than those of Group II, III and IV, the mean level of Group II was statistically higher than all other groups, and the mean level of Group III was statistically higher than Group V $(p<0.05)$. For TNF- $\alpha$ levels, no statistically significant difference was found between the mean scores of the groups $(p>0.05)$ (Table 6).

The minimum tissue MDA score was in Group I as 23.43 \pm 4.07 , whereas the maximum score was $88.02 \pm 9.03$ in Group II. The difference between the groups was statistically significant $(\mathrm{p}<0.0 \mathrm{I})$. The minimum tissue MPO score was in Group I as $833.25 \pm 16.3$, whereas the maximum score was in Group II as $1911.8 \pm 623.9$ (Table 7). The difference between the groups was statistically significant $(p<0.01)$.

Table 3. Distribution of groups' serum aspartate aminotransferase and alanine aminotransferase scoress

\begin{tabular}{lccccc}
\hline & Group I & Group 2 & Group 3 & Group 4 & Group 5 \\
\hline Aspartate aminotransferase IU/L & $37.05 \pm 23.99$ & $101.13 \pm \mid 4.91$ & $57.18 \pm \mid 1.2$ & $52.14 \pm \mid 1.95$ & $48.53 \pm \mid 14.88$ \\
Alanine aminotransferase IU/L & $31.48 \pm 5.12$ & $77.61 \pm 22.18$ & $35.19 \pm 6.93$ & $32.34 \pm 10.15$ & $33.81 \pm 5.62$ \\
\hline
\end{tabular}

Table 4. Statistical analysis of groups' serum AST and ALT scores

\begin{tabular}{|c|c|c|c|c|c|c|c|c|c|c|c|}
\hline Groups & & I-2 & $1-3$ & $\mathrm{I}-4$ & $I-5$ & $2-3$ & $2-4$ & $2-5$ & $3-4$ & $3-5$ & 4-5 \\
\hline Aspartate aminotransferase & $\mathrm{P}^{*}$ & $0.003^{* *}$ & 0.071 & 0.071 & 0.121 & $0.001^{\text {*k }}$ & $0.001^{* *}$ & $0.00 I^{* *}$ & 0.294 & 0.115 & 0.563 \\
\hline Alanine aminotransferase & $\mathrm{p}^{*}$ & $0.005^{* *}$ & 0.302 & 0.245 & 0.519 & $0.002^{* *}$ & $0.003^{* *}$ & $0.002^{* *}$ & 0.834 & 0.99 & 0.674 \\
\hline
\end{tabular}

Table 5. Distribution of groups' serum TNF- $\alpha$ and myeloperoxidase (MPO) levels

\begin{tabular}{lccccc}
\hline & Group I & Group 2 & Group 3 & Group 4 & Group 5 \\
\hline TNF- $\alpha$ & $176.67 \pm 56.15$ & $245.88 \pm 62.12$ & $220.5 \pm 45.02$ & $211.13 \pm 51.35$ & $210.88 \pm 86.41$ \\
MPO & $7.64 \pm 0.63$ & $24.25 \pm 6.05$ & $14.24 \pm 2.83$ & $11.95 \pm 5.36$ & $11.18 \pm 3.53$ \\
\hline
\end{tabular}

Table 6. Statistical analysis of groups regarding serum TNF- $\alpha$ and myeloperoxidase (MPO) levels

\begin{tabular}{llcccccccccc}
\hline & & I-2 & I-3 & I-4 & I-5 & $\mathbf{2 - 3}$ & $\mathbf{2 - 4}$ & $\mathbf{2 - 5}$ & $\mathbf{3 - 4}$ & $\mathbf{3 - 5}$ & $\mathbf{4 - 5}$ \\
\hline TNF- $\alpha$ & $\mathrm{P}^{*}$ & 0.07 & 0.09 & 0.27 & 0.52 & 0.25 & 0.21 & 0.19 & 0.29 & 0.46 & 0.75 \\
MPO & $P^{*}$ & $0.002^{* *}$ & $0.002^{* *}$ & $0.010^{* *}$ & 0.156 & $0.002^{* *}$ & $0.005^{* *}$ & $0.00 I^{* *}$ & 0.093 & $0.040^{* *}$ & 0.916 \\
\hline
\end{tabular}

*Mann-Whitney $U$ test; **Statistically significant difference; $\mathrm{p}$ : $\mathrm{p}$-value. 
Table 7. Distribution of groups' tissue malondialdehyde (MDA) and myeloperoxidase (MPO) scores

\begin{tabular}{lccccc}
\hline & Group I & Group 2 & Group 3 & Group 4 & Group 5 \\
\hline MDA & $23.43 \pm 4.07$ & $88.02 \pm 9.03$ & $36.27 \pm 21.92$ & $33.92 \pm 29.53$ & $36.68 \pm 35.56$ \\
MPO & $833.25 \pm 16.3$ & $1911.8 \pm 623.9$ & $1344.1 \pm 433.28$ & $1396.47 \pm 424.98$ & $1203.91 \pm 448.12$ \\
\hline
\end{tabular}

Table 8. Statistical analyses of groups' tissue malondialdehyde (MDA) and myeloperoxidase (MPO) scores

\begin{tabular}{|c|c|c|c|c|c|c|c|c|c|c|c|}
\hline & & I-2 & $1-3$ & I-4 & I-5 & $2-3$ & $2-4$ & $2-5$ & $3-4$ & $3-5$ & 4-5 \\
\hline MPO & $\mathrm{P}^{*}$ & $0.002^{* *}$ & $0.002^{* *}$ & $0.002^{* *}$ & $0.020^{* *}$ & $0.012^{* *}$ & $0.012^{* *}$ & $0.012^{* *}$ & 0.563 & 0.294 & 0.401 \\
\hline MDA & $p^{*}$ & $0.002^{* *}$ & 0.916 & 0.09 & 0.094 & $0.002^{* *}$ & $0.002^{* *}$ & $0.002^{* *}$ & 0.916 & 0.529 & 0.294 \\
\hline
\end{tabular}

Since the differences between the groups concerning tissue MDA and MPO scores were significant, we compared the groups pairwise. The tissue MPO score of Group I was significantly lower than all other groups, and the score of Group II was significantly higher than all other groups $(p<0.05)$. The tissue MDA score of Group II was significantly higher than all other groups $(p<0.05)$ (Table 8$)$.

\section{DISCUSSION}

To our knowledge, this is the first study that has evaluated the efficacy of a levosimendan and n-acetylcysteine combination in an experimental liver ischemia/reperfusion injury model. Various hepatic ischemia models have been used in the literature. ${ }^{[1-4]}$ In previous studies, total (100\%) liver ischemia, in which the damage was created without deteriorating hemodynamic stability, lasted a minimum of 25 minutes. The longest duration reported for ischemia in experimental studies was 90 minutes, whereas the duration of acceptable hot ischemia was reported to be approximately 60 minutes. ${ }^{[2-4]}$

The criticisms made in previous studies that partial ischemia models do not completely correspond to the clinical characteristics of total ischemia were considered, and total ischemia model was preferred in the present study. ${ }^{[4,5]}$ In our model, 60-minute duration was allocated to the total hot ischemia because of its similarity to clinical practice. When comparing the pseudo-implementation group and the ischemia-reperfusion group, both histopathological and biochemical differences were observed. Therefore, we believe that 60 minutes of clamping is enough for total liver ischemia.

Many agents and methods have been tried to reduce IRI. ${ }^{[4-7]}$ Increasing hepatic blood flow and controlling the inflammatory processes to limit the injury are gradually becoming more and more popular treatment methods used today. Physiological, pharmacological and structural treatment principles, such as the use of antioxidants, free radical and neutrophil inhibitors, ischemia preconditioning and hypothermia, have been tested to reduce or prevent liver injury, ${ }^{[4-7]}$ but no ideal method has yet been found.

Byrka-Owczarek et al. ${ }^{[8]}$ reported that the effectiveness of NAS is low in the bowel IRI. Although NAS is generally thought to be effective in reducing the effects of hot or cold ischemia of the liver, Chavez-Cartaya et al. ${ }^{\left[{ }^{[9]}\right.}$ found NAS to be ineffective in preventing reperfusion injury after experimental liver ischemia. Montero et al. ${ }^{[10]}$ reported that NAS made no contribution regarding reducing liver reperfusion injury. Moreover, Mojzis et al. ${ }^{\left[{ }^{\prime \prime}\right]}$ determined that NAS further increased gastric mucosal injury due to ischemia- reperfusion. Masahiro et al. ${ }^{[4]}$ studied the effects of various doses and implementation forms of NAS on ischemia-reperfusion injury in a rat myocardium IRI model. They determined that $150 \mathrm{mg} / \mathrm{kg} / \mathrm{hour}$ NAS infusion given 30 minutes before occlusion yielded lower MPO levels and smaller infarct zones than with the same dose of NAS given as a bolus. They stated that continuing the NAS concentration in the blood in the early reperfusion period is important to achieve the beneficial effect of NAS. In another animal study, Cuzzocrea et al. ${ }^{[12]}$ applied 45 minutes of splenic arterial occlusion and 60 minutes of reperfusion and then 20 $\mathrm{mg} / \mathrm{kg}$ bolus NAS and $20 \mathrm{mg} / \mathrm{kg} / \mathrm{hour}$ NAS infusion five minutes before the reperfusion. They reported that NAS decreased the levels of MPO and MDA. In their study on the effect of NAS on ischemia-reperfusion injury after partial hepatectomy in rats, Lee et al. ${ }^{[13]}$ applied 30 minutes of ischemia and 60 minutes of reperfusion after partial hepatectomy. They reported that NAS provided enzymatic and morphologic recovery in ischemia-reperfusion injury after partial hepatectomy. In the present study, we applied doses of $150 \mathrm{mg} / \mathrm{kg}$ for a 10 -minute loading dose of NAS and $20 \mathrm{mg} / \mathrm{kg} /$ hour for a maintenance infusion dose. In this study, NAS offered a significant decrease in tissue MDA and MPO levels and significantly reduced the liver IRI score from a histological aspect.

In their experimental study, Oktar et al. ${ }^{[14]}$ used levosimendan in liver injury induced by myocardial ischemia and reperfu- 
sion. They used a cycle of 60 minutes of ischemia and 60 minutes of reperfusion for rat liver and used levosimendan at a dose of $100 \mathrm{mcg} / \mathrm{kg}$. Finally, they concluded that levosimendan significantly ameliorates damage in a liver IRI model, especially when given before induction of ischemia. ${ }^{[14]}$ In our present study, the infusion of levosimendan was maintained during the reperfusion. In the levosimendan groups, both serum AST and ALT levels and histopathological injury score were significantly decreased.

Various injury-scoring systems were introduced to determine IRI and measure the level of injury. ${ }^{[10-14]}$ These scoring systems incorporate tissue changes in the cellular damage phases, and they are scored based on the level of findings. Even though they are relative, the method that most concretely reveals the actual tissue injury is histopathological examination. ${ }^{[10-14]}$

Crockett et al. ${ }^{[15]}$ observed sinusoidal congestion, cytoplasmic necrosis, and neutrophil infiltration and higher ALT levels in the IR group. Serracino-Inglott et al. ${ }^{[16]}$ reported polymorphonuclear leucocyte (PMNL) infiltration, hepatocyte necrosis, sinusoidal expansion, and an increase in ALT and AST levels. In this current study, we histopathologically analyzed the groups regarding sinusoidal congestion, cytoplasmic vacuolization and cellular necrosis using the Suzuki injury score. ${ }^{[17]} \mathrm{A}$ minimum injury score was achieved after the use of NAS plus levosimendan.

Yabe et al. ${ }^{[18]}$ asserted that AST and ALT levels in the liver increased after IR, and this increase may be due to the tissue injury caused by free radicals forming from IR. In the present study, we compared the combined and separate effects of levosimendan and NAS on serum AST and ALT values by comparing with the group given physiological saline solution. In the groups in which NAS and levosimendan were used together or alone, the levels of serum AST and ALT were significantly higher than in the group given physiologic saline solution. In addition, even though AST and ALT levels were lower in the group given the combination, the difference was not statistically significant.

Polymorphonuclear leukocytes (PMNs) constituting 60-70\% of the cellular defense system have a significant role in body defense. MPO enzyme activity plays an important role in PMNL defense mechanisms. ${ }^{[19]}$ The level of injury caused by activated PMNLs that have entered the inflammation zone can be measured by using the level of MPO in the inflammation zone. ${ }^{[19]}$

One of the most important structures targeted by IR-induced free radicals is lipids. Some researchers reported a key role of lipid peroxidation in ischemia-reperfusion injury. [20] Free oxygen radicals (FOR) initiate lipid peroxidation by taking a hydrogen atom from multiple unsaturated fatty acids, thus forming hydro-peroxides. At the end of these reactions, the cell membrane loses its viscosity, and the integrity of the membrane deteriorates. This also causes the release of cell fractions to the environment, as well as cell death. On the other hand, these subcellular structures released into the environment trigger inflammatory events and make the injury more severe. ${ }^{[2]}$ MDA is the final product of lipid peroxidation left in the tissue as the oxidative stress precursor, and it is a useful indicator of FOR formation. Hydrogen peroxide and FOR formed from IRI were reported to initiate the lipid peroxidation and protein injury and cause cell apoptosis and tissue necrosis, and it was reported that MDA emerged from lipid peroxidation. ${ }^{[20,21]}$

In their study with a rabbit spinal IR model, Katircioglu et al. ${ }^{[22]}$ implemented $12 \mathrm{mcg} / \mathrm{kg}$ loading dose of levosimendan for 10 minutes before the ischemia, then $0.2 \mathrm{mcg} / \mathrm{kg} / \mathrm{min}$ dose of infusion for 30 minutes of ischemia, and then reperfusion for 24 hours. They reported Tarlov score and MDA values to be statistically significantly lower than in the control group. In spinal cord ischemia-reperfusion injury, better histopathological results were achieved in the levosimendan group.

Sener et al. ${ }^{[23]}$ reported that NAS and melatonin decreased tissue MDA levels in a liver ischemia-reperfusion model when applied separately, and in combination, they decreased tissue MPO activity. They may further decrease ischemia-reperfusion injury through their synergistic effect.

In the present study, serum TNF- $\alpha$ and serum MPO levels were examined as local inflammation precursors to determine tissue MPO and systemic inflammation, and the inflammation and oxidative stress results of the groups were combined. In groups given levosimendan and NAS separately and in combination, tissue MDA levels and serum and tissue MPO levels were statistically significantly lower when compared with the group given physiological saline solution. When the study groups were compared with each other, no significant differences could be found. When used together or alone, NAS and levosimendan had positive effects on decreasing oxidative stress and suppressing inflammation. However, it can be stated that they had no advantage over each other in terms of preventing oxidative stress and suppressing inflammation.

TNF- $\alpha$ is released from macrophages and is an important activator cytokine. ${ }^{[24,25]}$ In addition to the cytotoxic effect, it also has important roles in inflammatory reaction and inflammation regulation. Kupffer cells are tissue macrophages localized in the liver. When activated, they release TNF- $\alpha$, as well as many cytokines. In addition, when stimulated, also neutrophils release TNF- $\alpha$ and myeloperoxidase. ${ }^{[24,25]} \mathrm{Neu}-$ trophils are believed to be the major agents responsible for the injury in inflammatory bowel disease, rheumatoid arthritis, cancer and reperfusion injury. TNF- $\alpha$ was reported to play an important role mainly in inflammatory conditions; in the presence of an infectious agent or in case of tissue injury, the increase is observed in TNF level in 4-8 hours, the peak 
level is achieved in 16-24 hours and, depending on the continuity of the stimulus, the release continues. ${ }^{[24,25]}$

In some experimental studies conducted previously, the cardioprotective, anti-inflammatory, and anti-apoptotic, ${ }^{[14,26]}$ anti-ischemic and anti-thrombocytic ${ }^{[27]}$ effects of levosimendan were reported. The findings suggest that levosimendan plays an effective role in immuno-inflammatory responses and yields a significant decrease in plasma TNF- $\alpha$ level. ${ }^{[26]}$

In our study, we observed the maximum serum TNF- $\alpha$ level in both the control group and the NAS and levosimendan combination group. The difference between the groups was not statistically significant. We think that the reason for this is that the whole procedure took only 120 minutes, and we created only local ischemia. Therefore, we think that serum TNF- $\alpha$ is not a useful marker for assessing injury in shortterm ischemia-reperfusion models, but tissue TNF- $\alpha$ levels may provide more useful information regarding IRI.

\section{Conclusion}

The use of a levosimendan plus NAS combination in liver IRI markedly suppressed inflammation and oxidative stress and significantly reduced liver ischemia-reperfusion injury and can be recommended for decreasing IRI instead of single-agent use of levosimendan or NAS.

This study also showed that tissue TNF- $\alpha$ level is a better indicator of injury in the short term and local IR than serum TNF- $\alpha$ level.

Ethics Committee Approval: This study approved by the Marmara University The Local Ethics Committee of Animal Experiments (Date: 14.12.2012, Decision No: 87.2012).

Peer-review: Internally peer-reviewed.

Authorship Contributions: Concept: B.B.G.; Design: S.S., S.Ö.; Supervision: S.Ö.; Resource: A.T.; Materials: S.S.; Data: S.S.; Analysis: S.S., S.Ö.; Literature search: S.S., B.B.G.; Writing: S.S., B.B.G., A.T.; Critical revision: B.B.G., A.T.

\section{Conflict of Interest: None declared.}

Financial Disclosure: The authors declared that this study has received no financial support.

\section{REFERENCES}

1. Toledo-Pereyra LH, Simmons RL, Najarian JS. Protection of the ischemic liver by donor pretreatment before transplantation. Am J Surg 1975;129:513-7. [CrossRef]

2. Tredger JM. Ischaemia-reperfusion injury of the liver: treatment in theory and in practice. Biofactors 1998;8:161-4. [CrossRef]

3. Jamali IN, Kersten JR, Pagel PS, Hettrick DA, Warltier DC. Intracoronary levosimendan enhances contractile function of stunned myocardium. Anesth Analg 1997;85:23-9. [CrossRef]

4. Masahiro A, Yoshiharu T, Satoshi I. Comparison of the protective effect of n-acetylcysteine by different treatments on rat myocardial ischemia-reperfusion injury. J Pharmacol Sci 2008;106:571-7. [CrossRef]
5. Grace PA. Ischaemia-reperfusion injury. Br J Surg 1994;81:637-47.

6. Carden DL, Granger DN. Pathophysiology of ischaemia-reperfusion injury.J Pathol 2000;190:255-66. [CrossRef]

7. Wang CY, Ni Y, Liu Y, Huang ZH, Zhang MJ, Zhan YQ, et al. Mild hypothermia protects liver against ischemia and reperfusion injury. World J Gastroenterol 2005;11:3005-7. [CrossRef]

8. Byrka-Owczarek K, Steplewska-Mazur K, Krasoń M, Bohosiewicz J, Koszutski T, Wojtynek G. The evaluation of the protective action of antioxidants on small intestine of rabbits experimentally injured by ischemia and reperfusion. J Pediatr Surg 2004;39:1226-9. [CrossRef]

9. Chavez-Cartaya R, Jamieson NV, Ramirez P, Marin J, Pino-Chavez G. Free radical scavengers to prevent reperfusion injury following experimental warm liver ischaemia. Is there a real physiological benefit?. Transpl Int 1999;12:213-21. [CrossRef]

10. Montero EF, Quireze C Jr, d'Oliveira DM. Bile duct exclusion from selective vascular inflow occlusion in rat liver: role of ischemic preconditioning and $\mathrm{N}$-acetylcysteine on hepatic reperfusion injury. Transplant Proc 2005;37:425-7. [CrossRef]

11. Mojzis J, Hegedüsová R, Mirossay L. Role of mucus in ischemia/reperfusion-induced gastric mucosal injury in rats. Physiol Res 2000;49:441-6.

12. Cuzzocrea S, Mazzon E, Costantino G, Serraino I, De Sarro A, Caputi AP. Effects of $\mathrm{n}$-acetylcysteine in a rat model of ischemia and reperfusion injury. Cardiovasc Res 2000;47:537-48. [CrossRef]

13. Lee EJS, da Silva SM, Simões MJ, Montero EFS. Effect of N-acetylcysteine in liver ischemia-reperfusion injury after $30 \%$ hepatectomy in mice. Acta Cir Bras 2012;27:346-9. [CrossRef]

14. Oktar GL, Demir Amac N, Elmas C, Arslan M, Goktas G, Iriz E, et al. The histopathological effects of levosimendan on liver injury induced by myocardial ischemia and reperfusion. Bratisl Lek Listy 2015;116:241-7.

15. Crockett ET, Galligan JJ, Uhal BD, Harkema J, Roth R, Pandya K. Protection of early phase hepatic ischemia-reperfusion injury by cholinergic agonists. BMC Clin Pathol 2006;6:3. [CrossRef]

16. Serracino-Inglott F, Virlos IT, Habib NA, Williamson RC, Mathie RT. Adenosine preconditioning attenuates hepatic reperfusion injury in the rat by preventing the down-regulation of endothelial nitric oxide synthase. BMC Gastroenterol 2002;2:22. [CrossRef]

17. Suzuki S, Toledo-Pereyra LH, Rodriguez FJ, Cejalvo D. Neutrophil infiltration as an important factor in liver ischemia and reperfusion injury. Modulating effects of FK506 and cyclosporine. Transplantation 1993;55:1265-72. [CrossRef]

18. Yabe Y, Kobayashi N, Nishihashi T, Takahashi R, Nishikawa M, Takakura Y, et al. Prevention of neutrophil-mediated hepatic ischemia/reperfusion injury by superoxide dismutase and catalase derivatives. J Pharmacol Exp Ther 2001;298:894-9.

19. Henderson JM. Liver transplantation and rejection: an overview. Hepatogastroenterology 1999;46:1482-4.

20. Peralta C, Prats N, Xaus C, Gelpí E, Roselló-Catafau J. Protective effect of liver ischemic preconditioning on liver and lung injury induced by hepatic ischemia-reperfusion in the rat. Hepatology 1999;30:1481-9.

21. Strieter RM, Kunkel SL, Bone RC. Role of tumor necrosis factor-alpha in disease states and inflammation. Crit Care Med 1993;21:S447-63.

22. Katircioglu SF, Seren M, Parlar AI, Turan NN, Manavbasi Y, Aydog G, et al. Levosimendan effect on spinal cord ischemia-reperfusion injury following aortic clamping. J Card Surg 2008;23:44-8. [CrossRef]

23. Sener G, Tosun O, Sehirli AO, Kaçmaz A, Arbak S, Ersoy Y, et al. Melatonin and $\mathrm{N}$-acetylcysteine have beneficial effects during hepatic ischemia and reperfusion. Life Sci 2003;72:2707-18. [CrossRef]

24. Semenzato G. Tumour necrosis factor: a cytokine with multiple biological activities. Br J Cancer 1990;61:354-61. [CrossRef]

25. Hillegass LM, Griswold DE, Brickson B, Albrightson-Winslow C. Assessment of myeloperoxidase activity in whole rat kidney. J Pharmacol Methods 1990;24:285-95. [CrossRef] 
26. Paraskevaidis IA, Parissis JT, Th Kremastinos D. Anti-inflammatory and anti-apoptotic effects of levosimendan in decompensated heart failure: a novel mechanism of drug-induced improvement in contractile performance of the failing heart. Curr Med Chem Cardiovasc Hematol Agents
2005;3:243-7. [CrossRef

27. Kaptan K, Erinç K, Ifran A, Yildirim V, Uzun M, Beyan C, et al. Levosimendan has an inhibitory effect on platelet function. Am J Hematol 2008;83:46-9. [CrossRef]

\title{
DENEYSEL ÇALIŞMA - ÖZ
}

\section{Levosimendan ve $\mathrm{N}$-Asetilsistein kombinasyonu deneysel karaciğer iskemi/reperfüzyon hasarı üzerine olumlu etkiler göstermektedir Dr. Serkan Suakıtıcı, ${ }^{1}$ Dr. Bülent Barış Güven, ${ }^{2}$ Dr. Alpaslan Tanoglu, ${ }^{3}$ Dr. Sezai Özkan ${ }^{4}$}

\author{
${ }^{1}$ Marmaris Devlet Hastanesi, Anesteziyoloji Kliniği, Muğla \\ ${ }^{2}$ Sağlık Bilimleri Üniversitesi, Sultan 2. Abdulhamid Han Eğitim ve Araştırma Hastanesi, Anesteziyoloji Kliniği, İstanbul \\ ${ }^{3}$ Sağlık Bilimleri Üniversitesi, Sultan 2. Abdulhamid Han Eğitim ve Araştırma Hastanesi, Gastroenteroloji Kliniği, İstanbul \\ ${ }^{4}$ Medipol Üniversitesi Çamlıca Hastanesi, Anesteziyoloji Kliniği, İstanbul
}

AMAÇ: İskemi/reperfüzyon hasarı (IRH), hipoksik bir organın yeniden oksijenlenmesi sonucu ortaya çıkan hücresel bir hasardır. Bu çalı̧mada, inotropik bir ajan olan levosimendan ile antioksidanların ve glutatyonun öncüsü olan N-Asetilsistein (NAS) kombinasyonunun deneysel bir karaciğer IRH modelindeki etkilerini incelemeyi amaçladık.

GEREÇ VE YÖNTEM: Otuz sekiz sıçan rastgele beş gruba ayrıldı. İskemiden önce çalışma gruplarına önceden belirlenmiş bir miktarda ve sürede fizyolojik salin çözeltisi, NAS, levosimendan veya NAS+levosimendan kombinasyonu verildi ve infüzyon çalışmanın sonuna kadar devam etti. Hepatik pedikül, bir atravmatik ven klempi kullanılarak bağlandı ve 60 dakikalık iskemi sağlandı. Daha sonra klemp açıldı ve 60 dakika reperfüzyon sağlandı. Karaciğer dokusu örnekleri sıçanlar sakrifiye edildikten sonra alındı ve doku malondialdehit (MDA) ve miyeloperoksidaz (MPO) seviyeleri belirlendi. Ayrıca alınan kan örneklerinden serum tümör nekrozis faktör (TNF)- $\alpha$, aspartat aminotransferaz (AST), alanin aminotransferaz (ALT) ve MPO düzeylerine de bakıldı.

BULGULAR: IRH sonrası karaciğer dokusundaki konjesyon, vakuolizasyon ve nekroz düzeylerine dayanarak oluşturulan histopatolojik hasar skorlama sisteminde gruplar arasında, histopatolojik değişiklikler bakımından, istatistiksel olarak anlamlı farklılıklar bulundu. Histopatolojik hasar skoru, plazma MPO, AST, ALT, doku MPO ve doku MDA değerleri, tedavi alan gruplarda kontrol gruplarına oranla istatistiksel olarak anlamlı derecede düşük bulunurken, levosimendan ve NAS kombinasyon grubunda karaciğer histopatolojik hasar skoru diğerlerine oranla istatistiksel olarak ciddi anlamda düşük bulundu.

TARTIŞMA: Literatürde ilk kez, karaciğer IRH'sında levosimendan ve NAS kombinasyonunun kullanılması ile enflamasyon ve oksidatif stresin belirgin şekilde baskılandığı ve karaciğer iskemisi reperfüzyon hasarının önemli ölçüde azaldığı gösterilmiştir. Bu sonuca göre, IRH durumunda levosimendan veya NAS'nin tek ajan olarak kullanımı yerine kombinasyon olarak kullanımı önerilebilir.

Anahtar sözcükler: İskemi/reperfüzyon hasarı; karaciğer; levosimendan; N-Asetilsistein.

Ulus Travma Acil Cerrahi Derg 2021;27(4):38I-388 doi: 10.14744/tjtes.2020.8I782 